\title{
Effects of tire inflation pressure and field traffic on compaction of a sandy clay soil as measured by cone index and permeability
}

\author{
S. Chehaibi ${ }^{1}$, M. Khelifi ${ }^{2 *}$, A. Boujelban ${ }^{1}$, K. Abrougui ${ }^{1}$ \\ ${ }^{I}$ Département du génie des systèmes horticoles, Institut supérieur agronomique de Chott-Mariem, 4042 Chott-Mariem, \\ Tunisia \\ ${ }^{2}$ Départment of Soils and Agri-Food Engineering, Université Laval, Quebec City, Quebec, Canada G1V 0A6 \\ *Email: mohamed.khelifi@fsaa.ulaval.ca
}

Chehaibi, S., M. Khelifi, A. Boujelban, K. Abrougui. 2012. Effects of tire inflation pressure and field traffic on compaction of a sandy clay soil as measured by cone index and permeability. Canadian Biosystems Engineering/Le génie des biosystèmes au Canada 54: 2.92.15. Many external factors have an effect on soil compaction, including the contact pressure generated at the soil-tire interface and the inflation pressure of tires. The main objective of this study was to investigate the effects of number of wheeled tractor passes and tire inflation pressures on the compaction and permeability of a sandy clay soil. Tests of soil compaction were conducted at the Higher Institute of Agronomy of Chott-Mariem, Sousse, Tunisia. Soil cone indices and permeability were measured under different number of tractor passes (one, two, and three) and tire inflation pressure $(50 \mathrm{kPa}, 100 \mathrm{kPa}$, and $150 \mathrm{kPa})$. A tractor of $59 \mathrm{~kW}$ with a total mass of $2,910 \mathrm{~kg}(1,715 \mathrm{~kg}$ on the rear axle) was used for the tests. Results showed that repeated passes increased soil compaction essentially in the upper horizons. This compaction, as measured by cone index, was positively correlated with tire inflation pressure. Indeed, the compaction was less pronounced under low tire inflation pressure. However, soil cone index remains closely related to soil moisture content. Multiple tractor passes also significantly reduce the soil permeability $(\mathrm{P}<0.05)$. Similarly, our results showed that the permeability was significantly affected by tire inflation pressure and considerably decrease when increasing the selected pressure $(50,100$, and 150 $\mathrm{kPa}$ ). However, the correct tire inflation pressure indicated by the manufacturer varies from 84 to $140 \mathrm{kPa}$. Keywords: Inflation pressure, repeated passes, soil compaction, soil cone index, permeability.

Plusieurs facteurs externes tels que la pression de contact générée à l'interface sol-pneu et la pression de gonflage des pneus ont un effet sur la compaction du sol. L'objectif principal de ce travail de recherche était d'examiner les effets de passages répétés d'un tracteur à pneumatique sur la compaction et la perméabilité d'un sol sableux-argileux sous différentes pressions de gonflage des pneus. Les essais de compaction du sol ont été effectués à l'Institut Supérieur Agronomique de Chott-Mariem, Sousse, Tunisie. L'indice de cône et la perméabilité du sol ont été mesurés sous différents passages du tracteurs (un, deux et trois) et pressions de gonflage des pneus $(50 \mathrm{kPa}$, $100 \mathrm{kPa}$ et $150 \mathrm{kPa}$ ). Un tracteur de $59 \mathrm{~kW}$ ayant une masse totale de $2910 \mathrm{~kg}$ (1 $715 \mathrm{~kg}$ sur l'essieu arrière) a été utilisé pour effectuer les essais. Les résultats montrent que les passages répétés augmentent la compaction du sol surtout dans les horizons supérieurs. Cette compaction est positivement corrélée avec la pression de gonflage des pneus. La compaction est moins prononcée sous de faibles pressions de gonflage. L'indice de cône du sol demeure toutefois étroitement lié à sa teneur en eau. Les passages multiples du tracteur au champ réduisent significativement la perméabilité du sol $(\mathrm{P}<0,05)$. De plus, cette perméabilité est largement affectée par la pression de gonflage étant donné qu'elle décroît de façon drastique avec l'augmentation de la pression choisie $(50,100$ et 150 $\mathrm{kPa})$. Cependant, la pression de gonflage indiquée par le constructeur varie de 84 à $140 \mathrm{kPa}$. Mots-clés: Pression de gonflage, passages répétés, compactage du sol, indice de cône du sol, perméabilité.

\section{INTRODUCTION}

Tunisia is currently experiencing an intensification of crop farming, especially in the irrigation sector, where tillage operations are now mechanized. The kinds of crops being grown require several agricultural operations to be done on a regular basis on wet soils over short time periods. These farming practices obviously run the risk of inducing permanent soil compaction that would increase gradually over time (Håkansson et al. 1988).

The main sources of soil compaction are directly or indirectly related to the development of agricultural mechanization (Vitlox 1997; Vitlox and Loyen 2002). Overuse of machinery has already been identified as the main reason contributing to soil compaction. Despite the soil mechanical strength, loading (in terms of axle load, tire dimensions and velocity) and soil-tire interaction contribute substantially to soil compaction (Defossez and Richard 2002; Hamza and Anderson 2005). The number of passes and the tire-soil contact pressure in particular are the main factors contributing to soil compaction (Raghavan et al. 1979; Vitlox and Loyen 2002; Saffih-Hdadi et al. 2009). In the same way, Taylor and Burt (1975) and Janzen et al. (1985) showed that compaction depends on the contact pressure at the wheel-soil interface. This pressure is more pronounced under rubber tire than under rubber tracks. 
Therefore, when soil characteristics are favourable to compaction, it is preferable to use equipment on tires with large contact areas, with ground pressure as low as possible (Ouézou 1999).

The extent of soil compaction mostly relies on soil stability, which is characterized by pre-consolidation stress, i.e., the level of pressure soil can withstand without risking permanent strain. If the pressure on the soil is greater than the pre-consolidation stress, compaction could be excessive. Otherwise, the soil undergoes elastic strain and returns to its original form as soon as the pressure ceases (Gysi 2001). According to Voorhees et al. (1978) and Allen and Musick (1997), soil cone indices measurements are more sensitive than density measurements when characterising soil compaction after several passes of the same agricultural equipment. These studies, conducted on clay loam soil (moisture content of 30 to $40 \%$ d.b.) showed that repeated tractor passes increase soil bulk density by $20 \%$ and increase soil cone index by $400 \%$ (Allen and Musick 1997).

In the study of the impact of the tractor passes number on soil density, Voorhees (1979) indicated that the most significant compaction over a depth of 0 to $75 \mathrm{~mm}$ occurred after the first pass in a clay soil with a moisture content of $38 \%$. After three passes, soil compaction reaches depths of 150 to $300 \mathrm{~mm}$. According to Soane et al. (1981) and Chehaibi et al. (2006), the effect of the second tractor pass was less pronounced than the first one. The optimal number of passes depends on the initial soil density. The effect of the first pass in terms of compaction on tilled soil was more significant than the subsequent passes as it caused the major proportion of total soil compaction (Hamza and Anderson 2005). However, the effects of the first and subsequent passes were similar on hard soil. Under several passes, the horizons close to the soil surface are mostly affected by compaction (Wiermann et al. 1999). In general, repeated passes of agricultural machinery at the same locations increase soil compaction (Chehaibi et al. 2005; Botta et al. 2009).

Allen and Musick (1992) and Allen and Schneider (1992) showed that tractor repeated passes in the field decrease infiltration by 12 to $80 \%$ in silt soils and by 20 to $35 \%$ in clay soils. Also, Eisenhauer et al. (1982) revealed that the tractor first pass after moldboard ploughing decreases soil infiltration by 20 to $25 \%$. The compaction of the ploughed area limits water infiltration, reduces roots establishment and development, and decreases the amount of available water and air in the vicinity (Allen and Musick 1997). The main objective of this research study was to investigate the effects of tractor repeated passes with rubber tires on the compaction of a sandy clay soil under different tire inflation pressures.

\section{MATERIALS AND METHODS}

The field study was carried out at the the Higher Agronomic Institute of Chott Meriem, Sousse (Tunisia). The trials were conducted on a $1.7 \%$ slope sandy silt soil (76.6\% sand, $15.3 \%$ silt, $8.1 \%$ clay) using a standard two- wheel-drive tractor equipped with single rear tires and having a total weight of $2,910 \mathrm{~kg}(1,715 \mathrm{~kg}$ on the rear axle) and a power of $59 \mathrm{~kW}$. The tractor without hitched load applied to it, was equipped with 7.00-16 bias-ply front tires and single 16.9-30 bias-ply rear tires (overall diameter $=1.45 \mathrm{~m}$; section width $=0.45 \mathrm{~m}$ ). The correct inflation pressure for the $1195 \mathrm{~kg}$ static load on each front tire was $84 \mathrm{kPa}$ and that for the $1715 \mathrm{~kg}$ static load on each rear tire was $140 \mathrm{kPa}$. The preliminary studies showed that the soil cohesion was $16 \mathrm{kPa}$ (Gill and Vanden Berg 1968), the Young's modulus was $13 \mathrm{kPa}$, and the poisson's ratio was 0.30 .

The experimental set-up was a split plot design with three tractor passes $(1,2$, and 3 times) assigned to main plots and three tire infiltration pressures $(\mathrm{P} 1=50 \mathrm{kPa}$, $\mathrm{P} 2=100 \mathrm{kPa}$, and $\mathrm{P} 3=150 \mathrm{kPa}$ ) as subplots. The main experimental plot area, 34 by $50 \mathrm{~m}$, tilled at a mean depth of $250 \mathrm{~mm}$, was split into three blocks corresponding to the tractor passes (Fig. 1). Each area was then split into three 5.5 -m-wide sub-plots for the three tested pressures. Each new pass was carried out 15 days after the previous one. Compaction tests consisted of driving the tractor along the same path (1,2 or 3 times) on the tilled soil (initial state E0). The tire tracks left on the ground after the first pass was used as a reference for the subsequent passes. Measurements were taken at six depths ranging from 0 to $250 \mathrm{~mm}$.

Soil cone index noted at different depths ranging from 0 to $250 \mathrm{~mm}$ was used to estimate the soil compaction. Soil cone index in wheel prints was determined according to Vitlox (1994), Viltox (1998), and Vitlox and Loyen (2002). A calibrated conic tip penetrometer (cone angle $=30^{\circ}$, cone base area $=320 \mathrm{~mm}^{2}$, dynamometric ring $=5 \mathrm{kN}$ force) was used for this purpose (Billot 1989). The tire contact projection areas for one rear tire were 144, 126, and 103.5 $\mathrm{mm}^{2}$ for inflation pressure of 50,100 , and $150 \mathrm{kPa}$, respectively. These values were chosen in the range of pressures indicated by the manufacturers. A tire contact projection area is the area of the tire contact patch, projected onto a horizontal plane. Tire-soil contact pressures were 117,133 , and $162 \mathrm{kPa}$, respectively, for $\mathrm{P} 1$, $\mathrm{P} 2$, and $\mathrm{P} 3$. These pressures were determined by dividing the static load on the tire by the tire contact projection area.

During the trials, tractor travel speed was $3.2 \mathrm{~km} / \mathrm{h}$ for $\mathrm{P} 1,3.12 \mathrm{~km} / \mathrm{h}$ for $\mathrm{P} 2$ and $3.02 \mathrm{~km} / \mathrm{h}$ for $\mathrm{P} 3$. These variations could be explained by the fact that a low pressure translates into a larger tire contact area at the soil interface, which improves adherence and consequently reduces slippage. Wheel slip on well-crumbled soil was $2.9 \%$ for $\mathrm{P} 1,3.2 \%$ for $\mathrm{P} 2$, and $3.35 \%$ for $\mathrm{P} 3$.

Soil permeability measurements were based on the computation of the permeability coefficient "K" according to Darcy's law (Musy and Scuter 1991). This coefficient mainly depends on the soil properties, especially soil structure (Hillel 1988). The permeability of different compacted horizons was assessed according to the Porchet 


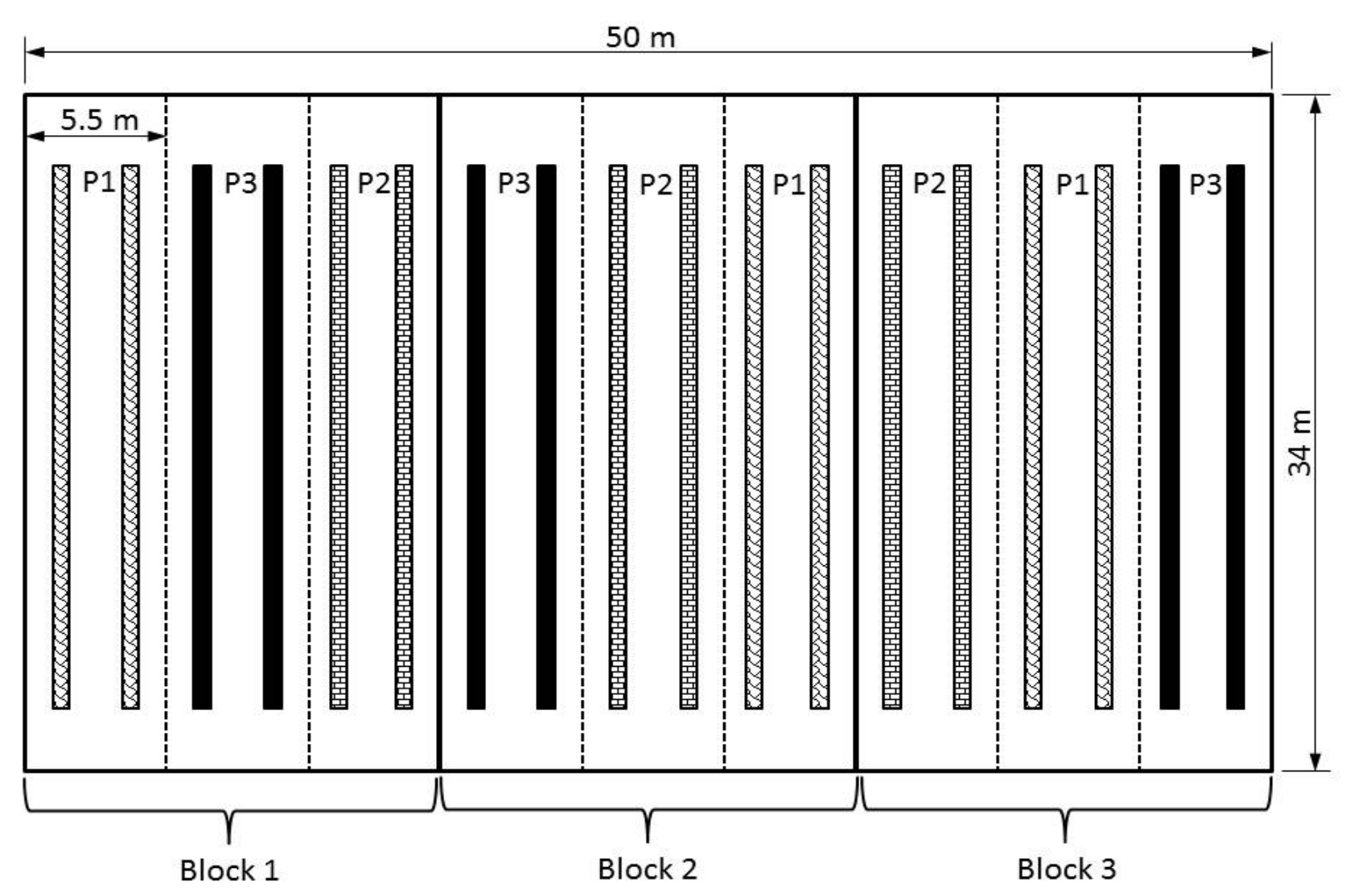

Fig. 1 Field experimental layout.

method, which involves digging a 60-mm-diameter hole to a depth of $300 \mathrm{~mm}$ and then filling it with water. Thereafter, changes in water level in the hole over time were computed using a scaled gauge.

During the trials, the average volumetric water content of the soil at the $0-300 \mathrm{~mm}$ horizon was $6.6 \%$ at the initial state, $13.5 \%$ after one pass of the tractor, $11.5 \%$ after two passes, and $9.8 \%$ after three passes. Soil water content and Soil cone index measurements were taken at the same time.

\section{Statistical analysis}

Analysis of variance was performed at the $5 \%$ level of significance using the MIXED procedure of the SAS Software (SAS Institute 2005) based on the variancecovariance structure that minimizes the Akaike criteria. This allowed assessing the effects of tractor passes and tire inflation pressures on the soil compaction and permeability. Multiple comparisons between significant parameters were carried out using the Tukey adjustment method (SAS Institute 2005).

\section{RESULTS AND DISCUSSION}

\section{Soil cone index}

The analysis of variance revealed that the effects of inflation pressure and passes on soil's cone indices at different depths were all highly significant $(\mathrm{p}<0.0001)$ (Table 1). Also, the interaction between inflation pressure and pass was highly significant.

Except for the second pass, where the moisture content was relatively high $(16.5 \%)$, soil cone index increased with passes and with increasing tire inflation pressure. This is also the case with increasing depth. However, the increase in soil cone index was more pronounced at the upper layers of the soil following the first pass under a pressure of $50 \mathrm{kPa}$.

Results of the first pass are shown in Fig. 2a. In its initial state $(6.6 \%$ average moisture content), the soil cone index was $70 \mathrm{kPa}$ on the ground surface, $750 \mathrm{kPa}$ at a depth of $100 \mathrm{~mm}$, and $1480 \mathrm{kPa}$ at $200 \mathrm{~mm}$. For an

Table 1. Analysis of variance of the soil's cone indices as influenced by the tire inflation pressures and the tractor passes

\begin{tabular}{lccc}
\hline Source & D.F. & F & Pr $>F$ \\
\hline Pressure & 2 & 294.26 & $<0.0001$ \\
Pass & 2 & $1,881.08$ & $<0.0001$ \\
Pressure*Pass & 4 & 17.06 & $<0.0001$ \\
\hline
\end{tabular}



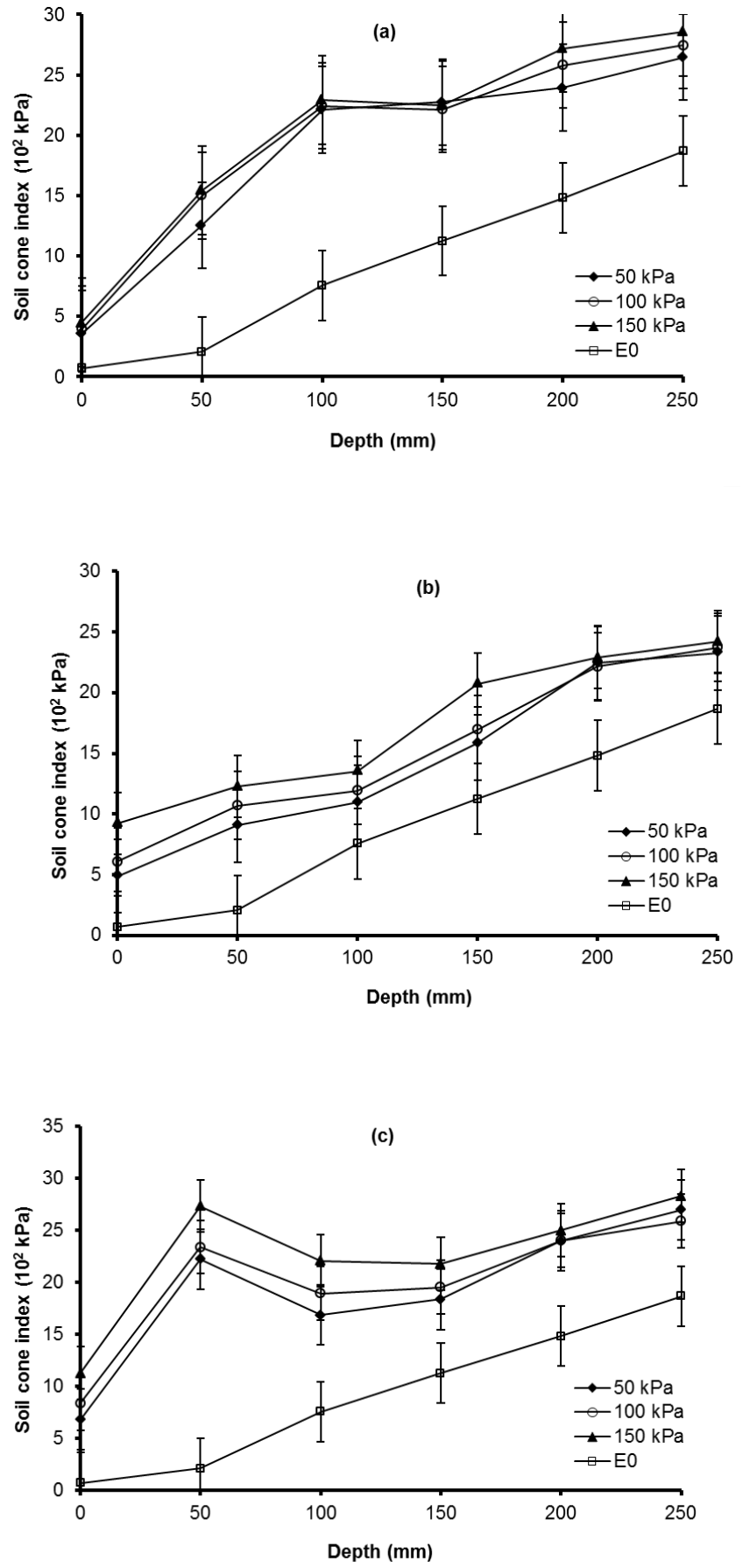

Fig. 2 Soil cone index at different depths for different inflation pressures: (a) after one pass, (b) after two passes, and (c) after three passes.

inflation pressure of $50 \mathrm{kPa}$ (average moisture content of $13.5 \%$ ), the soil cone index varies from $350 \mathrm{kPa}$ on the ground surface to $2210 \mathrm{kPa}$ and $2390 \mathrm{kPa}$ at $100 \mathrm{~mm}$ and $200 \mathrm{~mm}$ depths, respectively. For the same depths, an inflation pressure of $100 \mathrm{kPa}$ results in soil cone indices of $390 \mathrm{kPa}, 2240 \mathrm{kPa}$ and $2580 \mathrm{kPa}$, respectively, whereas an inflation pressure of $150 \mathrm{kPa}$ induced soil cone indices of $450 \mathrm{kPa}, 2290 \mathrm{kPa}$, and $2720 \mathrm{kPa}$. At the three depths $(0$ $\mathrm{mm}, 100 \mathrm{~mm}$, and $200 \mathrm{~mm}$ ), the average increase of soil cone index compared to the initial state is $405 \%, 192 \%$, and $62 \%$ under a tire inflation pressure of $50 \mathrm{kPa} ; 459 \%$, $193 \%$, and $74 \%$ under $100 \mathrm{kPa}$ of pressure; and $539 \%$, $203 \%$ and $84 \%$ under $150 \mathrm{kPa}$ of pressure. These results show that the pass of a tire subjected to different inflation pressures on a tilled soil increases the soil cone index. This increase is higher under a pressure of $150 \mathrm{kPa}$ and the upper horizons are the most affected.

After the second pass (average moisture content of $16.5 \%$ ), the profile of soil cone index is similar to that after the first pass (Fig. 2b). The resistance on the ground surface increases, whereas it decreases at deeper horizons whatever the inflation pressures. At the ground surface, soil cone index increases by $38 \%, 55 \%$, and $106 \%$ for the three inflation pressures $(50,100$, and $150 \mathrm{kPa})$. At the two depth ranges, "100 to $150 \mathrm{~mm}$ " and "200 to $250 \mathrm{~mm}$ ", soil cone index decreases by $50 \%$ and $6 \%$ for the inflation pressure of $50 \mathrm{kPa}, 47 \%$ and $14 \%$ for the inflation pressure of $100 \mathrm{kPa}$, and $41 \%$ and $16 \%$ for the inflation pressure of $150 \mathrm{kPa}$. These results show that the pressure exerted by the tire during the first pass did not induce a permanent strain on the soil at depth. The resulting strain after the first pass is then elastic. By the time of the second pass, that strain had already disappeared. A $12 \mathrm{~mm}$ rain shower that occurred between the first and second passes contributed to this phenomenon. Also, it is important to mention that the moisture content of the soil was relatively high when taking the measurements $(16.5 \%)$. This explains the decrease in soil index at different depths below the ground surface after the second pass.

Results obtained after the third pass of the tractor (average moisture content of 9.8\%) are presented in Fig. 2c. These results clearly indicate a significant increase in soil cone index for all the considered depths. Following the third pass, the soil is mostly affected at a depth of 50 $\mathrm{mm}$. Indeed, soil cone indices under an inflation pressure of $50 \mathrm{kPa}$ are $680 \mathrm{kPa}, 2220 \mathrm{kPa}$, and $1680 \mathrm{kPa}$ on the ground surface and at $50 \mathrm{~mm}$ and $100 \mathrm{~mm}$ of depth, respectively. For the same depths $(0 \mathrm{~mm}, 50 \mathrm{~mm}$, and 100 $\mathrm{mm})$, soil cone indices are $830 \mathrm{kPa}, 2340 \mathrm{kPa}$ and $1840 \mathrm{kPa}$ under an inflation pressure of $100 \mathrm{kPa}$ and 1130 $\mathrm{kPa}, 2730 \mathrm{kPa}$ and $2200 \mathrm{kPa}$ under an inflation pressure of $150 \mathrm{kPa}$. These results demonstrate that repeated passes of a tractor in the same path lead to excessive compaction of the soil. Soil cone index was a more sensitive indicator of soil compaction than was bulk density. Wheel traffic increased soil cone index by as much as $400 \%$. At a high inflation pressure, the depth of the tractor tire tracks prints left in the field could easily identify the compaction. This confirms again that repeated traffic in the field mostly affects the upper horizons of the soil.

Overall, the results show an increase in soil cone index following the pass of the tractor, especially in the upper horizons. This increase is more pronounced with 


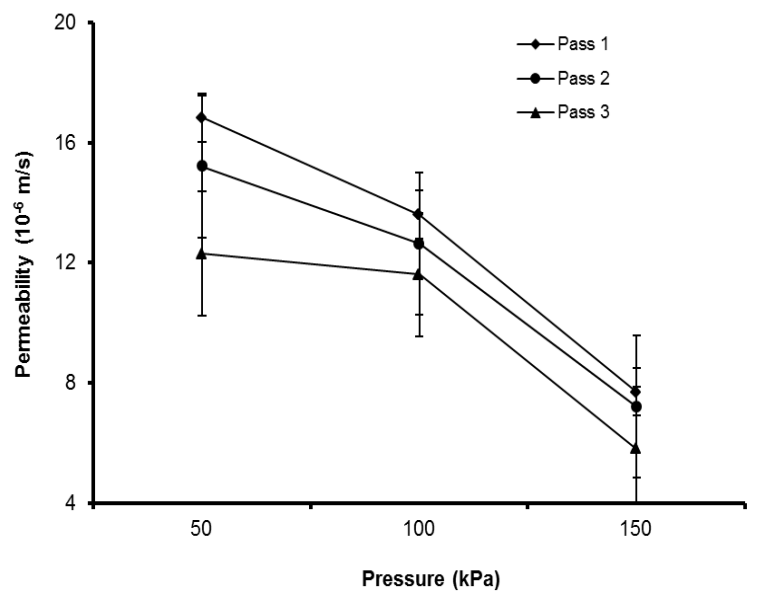

Fig. 3 Effects of tire pressure and tractor passes on soil permeability.

high tire inflation pressures. These results corroborate those obtained by Séguy et al. (1984), Blanceaux et al. (1993), Chehaibi et al. (2005) and Chehaibi et al. (2006), which showed that soil horizons close to the ground surface are most affected by compaction following multiple passes of agricultural equipment. The study by Güclü et al. (2002) also showed that for row crops, repeated passes of agricultural machinery compact the soil to the same degree as what it was before ploughing. Our results also agree with those of Vitlox and Loyen (2002), who proved that high inflation pressures generate greater compaction.

Our study also shows that the first pass caused the most compaction. This result confirms that of Soane et al. (1981), who found that on tilled ground the effects of the first pass are more important than those of subsequent passes. Muro (1992) and Hoogmoed (1994) also showed that $80 \%$ of soil compaction by tractor wheels results from the first pass. Therefore, soil compaction could be considerably reduced by always driving in the same path.

\section{Soil permeability}

The analysis of variance of the data revealed that the effects of the inflation pressure and the number of passes on soil permeability were highly significant $(p<0.0001)$ (Table 2). Also, the interaction between pressure and pass was highly significant $(\mathrm{p}<0.0001)$.

Overall, tractor travel in the field reduced the permeability of the soil. This reduction in permeability was more pronounced with the increase in the number of passes (Fig. 3). Also, the more the tires are inflated, the less the soil is permeable. Based on soil permeability at the initial state $\left(18.2 \times 10^{-6} \mathrm{~m} / \mathrm{s}\right)$, Fig. 3 shows that soil permeability is reduced by $7.4 \%, 25 \%$ and $57.6 \%$ following the first pass of the tractor, $16.3 \%, 30.5 \%$ and $60 \%$ following the second pass, and $32 \%, 36 \%$ and $68 \%$ following the third pass under the tire inflation pressures of 50,100 and $150 \mathrm{kPa}$, respectively. These results
Table 2. Analysis of variance of the permeability as influenced by the tire inflation pressures and the tractor passes

\begin{tabular}{lccc}
\hline Source & D.F. & F & Pr $>$ F \\
\hline Pressure & 2 & 323.27 & $<0.0001$ \\
Pass & 2 & $2,905.55$ & $<0.0001$ \\
Pressure*Pass & 4 & 34.40 & $<0.0001$ \\
\hline
\end{tabular}

emphasize the effect of a high tire inflation pressure characterised by a smaller contact area at the soil interface and a higher soil pressure on soil compaction (high soil cone index). According to Richard (2008) and SaffihHdadi et al. (2009), excessive soil compaction results in the decrease of soil porosity under tractor wheels and in the formation of ruts at the soil surface.

Obtained results confirm those of Eisenhauer et al. (1982), who showed that the first pass of a wheeled tractor after ploughing reduces water infiltration in the soil, and those of Vitlox and Loyen (2002), who found that water infiltration in the soil was highly affected by compaction $(19.6 \mathrm{~mm} / \mathrm{h}$ for a non-compacted soil against $3.2 \mathrm{~mm} / \mathrm{h}$ for a compacted soil). Our results are also consistent with those of Kemper et al. (1982), who found that repeated passes of a wheeled tractor in row crops reduce soil infiltration by $12 \%$ to $80 \%$. The studies by Allen and Musick (1992) and Allen and Schneider (1992) also indicated that multiple passes of a tractor in the field reduce irrigation infiltration by $20 \%$ to $35 \%$.

\section{CONCLUSIONS}

Repeated travel of a tractor tire carrying the same load and increasing inflation pressures result in increased soil compaction. All soil horizons are affected by this compaction, but those closer to the ground surface are the most compacted. However, compaction was found to be less pronounced under tire tracks made by tires with low inflation pressures.

Soil cone index is closely related to the pressure induced to the soil, which is amplified by the wheel-soil contact. This pressure applied to the ground surface is a function of the load placed on the wheel and the type of wheel-soil contact. A wheel with a low-inflated tire minimizes the pressure resulting from the contact with the ground surface.

The increased number of tractor passes in the field also increases soil compaction. This compaction remains, however, closely related to the moisture content of the soil. After several passes, the upper horizons of the soil are the most compacted.

The increase in soil compaction following repeated passes of a tractor in the field greatly reduces the permeability of the soil. This permeability is also highly affected by the tire inflation pressure, decreasing dramatically as the pressure increases from $50 \mathrm{kPa}$ to 150 $\mathrm{kPa}$. 


\section{ACKNOWLEDGEMENT}

The authors are grateful to Mr. Kamel Ben M'Barek for his assistance in planning this experiment and analysing the data and to Mr. Tawfik Bouaouina for his assistance in carrying out the tests.

\section{REFERENCES}

Allen, R.R. and A.D. Schneider. 1992. Furrow water infiltration reduction with surge irrigation or traffic compaction. Applied Engineering in Agriculture 8(4): 455-460.

Allen, R.R. and J.T. Musick. 1997. Furrow irrigation infiltration with multiple traffic and increased axle mass. American Society of Agricultural Engineers 13(1): 49-53.

Allen, R.R. and J.T. Musick. 1992. Furrow traffic and ripping for control of irrigation infiltration. Applied Engineering in Agriculture 8(2): 243-248.

Billot, J.F. 1989. Pénétrométrie, choix des outils et dates de travail du sol. In Land and Water Use, eds. V.A. Dodd and P. M Grace, 1729-1736. Rotterdam, The Netherlands: Balkema.

Blanceaux, P., P.L. De Freitas, R.F. Amabile and A. De Carvalho. 1993. Le semis direct comme pratique de conservation des sols des cerrados du Brésil central. Cahiers ORSTOM, série Pédologie (28) 2: 253-275.

Botta, G.F., A. Tolon Becerra and F. Bellora Tourn. 2009. Effect of the number of tractor passes on soil rut depth and compaction in two tillage regimes. Soil and Tillage Research 103: 381-386.

Chehaibi, S., E. Hamza, J.G. Pieters and R. A. Verschoore. 2005. Tassement du sol par les passages répétés des matériels de traction dans le secteur maraîcher. Revue de l'INA de Tunisie (20)1 : 7-18.

Chehaibi, S., E. Hamza, J.G. Pieters and R.A. Verschoore. 2006. Effets des engins de traction sur le tassement du sol: une analyse comparative. Annales de L'INRGREF de Tunisie 8: 157-170.

Defossez, P. and G. Richard. 2002. Models of soil compaction due to traffic and their evaluation. Soil and tillage Research 67: 41-64.

Eisenhauer D.E., E.C. Dickey, P.E. Fischbach and K.D. Frank. 1982. Influence of reduced tillage on furrow irrigation infiltration. ASAE Paper No 82-2587. St. Joseph, MI: ASABE.

Gill, W.R. and G.E. Vanden Berg. 1968. Soil dynamics in tillage and traction. Agriculture Handbook 316. Washington, DC: U.S. Government Printing Office.

Güclü, Y., H.M. Vatandas and R. Gürhan. 2002. Soil strength as affected by tillage system and wheel traffic in wheat-corn rotation in central Anatolia. Journal of Terramechanics 39: 23-34.

Gysi, M. 2001. Compactage du sol: préconsolidation à titre de mesure de stabilité. FAT Report 566. Ettenhausen, France: Station fédérale de recherches en économie et technologie agricoles (FAT), 8356.
Håkansson, I., W.B. Voorhees and H. Riley. 1988. Vehicle and wheel factors influencing soil compaction and crop response in different traffic regimes. Soil and Tillage Research 11:239-282.

Hamza, M.A. and W.K. Anderson. 2005. Soil compaction in cropping systems: A review of the nature, causes and possible solutions. Soil and Tillage Research 82: 121-145.

Hillel, D. 1988. L'eau et le Sol: Principes et Processus Physiques, $2^{\text {ème }}$ édition. La Neuve, Laval : Université catholique de Louvain.

Hoogmoed, W. 1994. Caractéristiques physiques du sol: caractéristiques liées au travail du sol. In Le Travail du Sol pour une Agriculture Durable, eds. W.B. Hoogmoed and M.C. Klaij, chapter 7. Niamey, Niger: FAO - Organisation des Nations Unies pour l'alimentation et l'agriculture. http://www.fao.org/docrep/W7304F/w7304f00.htm\#C ontents $(2012 / 04 / 01)$.

Janzen, D.C., R.E. Hefner and D.C. Erbach. 1985. Soil and corn response to track and wheel compaction. In Proceedings of the International Conference on Soil Dynamics, 5:1023-1038. Auburn, AL. June 17-19.

Kemper, W.D., B.J. Ruffing, J.A. Bondurant. 1982. Furrow infiltration rates and water management. Transactions of the ASAE 25(2): 333-339.

Muro, T. 1992. Application height control system of a bulldozer towing a scraper down a weak slope terrain during braking action. Soils and Foundations 32(2): 125-33.

Musy, A. and M. Scuter. 1991. Physique du Sol, $1^{\text {ère }}$ édition. Lausanne, Suisse : Presses Polytechniques et Universitaires Romandes.

Ouézou, Y.A. 1999. Protection des sols en culture mécanisée. Cahiers agricultures (8)3: 189-195.

Raghavan, G.S.V., E. McKyes and F. Taylor. 1979. Soil compaction effects on soil productivity. Report. St. Anne de Bellevue, P.Q., Canada: Department of Agricultural Engineering, Macdonald College of McGill University.

Richard, G. 2008. Dégradation physique des sols agricoles et forestiers liée au tassement. Report ADD and GESSOL. Orléans, France: Unité de recherche Science du Sol, Institut national de la recherche agronomique.

Saffih-Hdadi, K., P. Défossez, G. Richard, Y.-J. Cui, A.M. Tang and V. Chaplain. 2009. A method for predicting soil susceptibility to the compaction of surface layers as a function of water content and bulk density. Soil and Tillage Research 105: 96-103.

SAS Institute. 2005. SAS OnlineDoc 9.1.3. Cary, NC: SAS Institute Inc.

Séguy, L., J. Kluthhcouski, J.G. da Silva, F.N. Blumenschin and F.M. Dall'Acqua. 1984. Técnicas de preparo do solo: efeitos na fertilidade e na conservação do solo, nas ervas daninhas e na 
conservação de água (Technique of preparing the soil, effects on fertility and soil conservation, the weeds and the water conservation). Circular Técnica (INFOTECA-E) 1357. Goiania, Brazil: EMBRAPACNPAF.

Soane, B.D., P.S. Blackwell, J.W. Dickson and D.J. Painter. 1981. Compaction by agricultural vehicles: A review II. Compaction under tires and other running gear. Soil and Tillage Research 1: 373-400.

Taylor, J.H. and E.C. Burt. 1975. Track and tire performance in agricultural soils. Transactions of the ASAE 18(4):3-6.

Vitlox, O. and S. Loyen. 2002. Conséquences de la mécanisation sur la compaction du sol et l'infiltration de l'eau. In Compte rendu de la journée d'étude: Erosion hydrique et coulées boueuses en Région Wallonne, 45-58. Gembloux, Belgique. May 31.

Vitlox, O. 1994. Compaction des sols. Etat de l'environnement Wallon, sol, climat, microorganismes, tourisme. Report. Namur, Belgique : Direction générale des ressources naturelles et de l'environnement, Ministère de la région Wallone.
Vitlox, O. 1997. Nouvelles alternatives en matière de travail du sol: conséquences agronomiques et critères de choix. In Aspects mecaniques de la preparation $d u$ sol, 40-56. Centre de Recherche Agronomique de Gembloux, Belgique. December 17.

Vitlox, O. 1998. Répartition de la pression de contact des pneumatiques déterminée par la mesure de déformation du sol. Report, Journée à thème conjointe de Pédologie et de Génie Rural. Gembloux, Belgique: Faculté Universitaire des Sciences Agronomiques de Gembloux (FUSAGx).

Voorhees, W.B. 1979. Energy aspects of controlled wheel traffic in the northern Corn Belt of the United States. In Proceedings of the 8th Conference of the International Soil Tillage Research Organization, 333-338. Stuttgart, W. Germany. September 10-14.

Voorhees, W.B., C.G. Senst and W.W. Nelson. 1978. Compaction and soil structure modification by wheel traffic in the northern Com Belt. Soil Science Society of America Journal 42(2): 344-34.

Wiermann, C., T.R. Way, R. Horn, A.C. Bailey and E.C. Burt. 1999. Effect of various dynamic loads on stress and strain behavior of a Norfolk sandy loam. Soil and Tillage Research 50:127-135. 